available — but many exist as fragments of : the complete cDNA. In addition, the lack of : proper categorization, and inconsistencies between the various databases, limits the usefulness of the sequences for research.

"The data will be well-defined and quality controlled through the checks and balances of over a hundred scientists," says Ranajit Chakraborty, director of the Center for Genome Information at the University of Cincinnati Medical Center in Ohio.

To create the data set, the researchers mapped 42,000 cDNAs, collected from six databases around the world, to some 23,000 different regions on the human genome. The overlap of many cDNAs at the same regions will shed light on one of the mysteries of the genome - how so few genes can make the range of proteins that carry out the many functions in human development, and also produce so much variety in people's genetically determined features.

One explanation is that the genes undergo alternative splicing, whereby various mRNAs are produced from the same genomic sequence. By looking at many slightly different cDNAs that cover the same gene regions, researchers say that they will find many examples of these alternate forms of mRNA.

The meeting also offered a large data set, and a platform for debate, concerning non-coding RNA, which does not make protein. Some researchers believe such non-coding RNA has a major role in regulating gene expression, but the idea remains controversial (see Nature 418, 122-124; 2002).

www.jbirc.aist.go.jp/index_E.html

www.ddbj.nig.ac.jp

\title{
Name-calling gets stem-cell researcher into hot water
}

\section{Carina Dennis, Sydney}

If you ever find yourself called from the lab bench to testify on a contentious topic, here's a cautionary tale: a prominent stemcell researcher is this week licking his wounds after being accused of misleading the Australian public over the potential of embryonic stem-cell research.

Alan Trounson, who directs a developmental-biology centre at Monash University in Melbourne, has been widely denounced in the news media for a technical inaccuracy made during briefings to members of parliament. Opponents of the research rounded on the error as evidence that scientists were wilfully misrepresenting their findings.

"As a scientist whose integrity has been put at stake by people with an axe to grind, it has been terrible for me, and the impact on my family has been awful," says a drained Trounson, who was hospitalized last week for a heart condition.

Trounson showed parliamentarians a video of the recovery of a paralysed rat following injection of what he said were human embryonic stem cells. But the cells were embryonic germ cells — strictly speaking, cells from the parts of 5-9-week-old embryos and fetuses from which eggs and sperm later form. Embryonic stem cells are derived from embryos that are just a few days old. The video was taken at the lab of John Gearhart, a biologist at Johns Hopkins University, Baltimore, but the experiment's results have yet to be published.

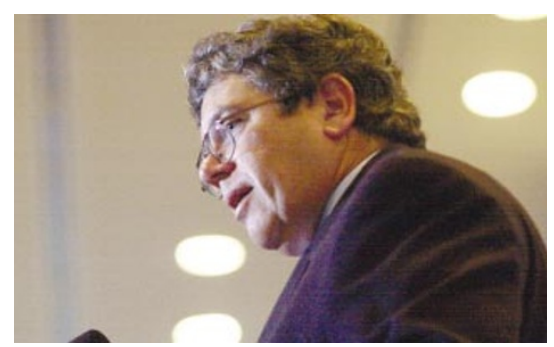

Tongue-tied: Alan Trounson's attempts to simplify science for parliament backfired in the media.

Although Trounson acknowledges the error, he defends his actions. "Embryonic germ cells had never been explained to these parliamentarians before, so I simplified and just called them embryonic stem cells," he says. "This is not absolutely correct, but they are embryonic and they are stem cells and you can't tell the difference between them."

Several biologists have jumped to Trounson's defence. But he advises others to step gingerly when providing information to politicians. "Be very careful about taking these matters forward unless you get a professional organization to help you, in terms of handling the media and the politics," he says. "You just can't do it yourself."

Australia is currently looking at legislation to regulate human cloning and stem-cell research. Last week, parliament voted to pass a blanket ban on human cloning and to defer the vote on embryonic stem-cell research untillater this month.

\section{Dispute over first authorship lands researchers in dock}

\section{Alison Abbott, Munich}

Rows about the order of authors' names on a research paper can get stormy at times but they don't often end up in court. That's what has happened, however, in a dispute between two molecular biologists at Germany's University of Göttingen.

The paper in question - an analysis of a tyrosine kinase receptor of relevance to cancer - had been jointly prepared by Marco Ledwon, a former PhD student at the university, and Frauke Alves, the leader of the research team, for submission to the journal Biological Chemistry.

But Ledwon, who now works for Lower Saxony's Association of Libraries, took legal action in February, before the paper was submitted, alleging that Alves had substituted her name for his as first author on the final draft without reasonable cause.
The state court of Lower Saxony slapped an immediate injunction on Alves to prevent her submitting the paper for publication

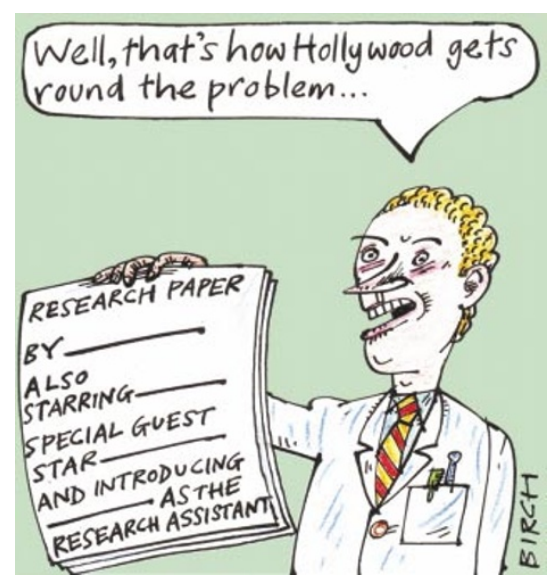

until the court had made a considered ruling.

A few weeks ago, the court ruled in favour of Ledwon. But it did not base its ruling on the relative intellectual contributions of Ledwon and Alves to the paper. Instead it said that the original verbal agreement that Ledwon should be first author had not been disputed in the 14 months during which the paper was being prepared. This understanding constituted an implicit contract, the court said, which Alves had broken.

According to Laborjournal, the magazine that first reported the case, Alves contends that Ledwon made insufficient research contribution to warrant first authorship. But Ledwon says he carried out experiments independently and helped to write the paper. The paper has not yet been submitted for publication and the University of Göttingen declined to comment on the case. 